\title{
Effects of a natural multi-component compound formulation on the growth, morphology and extracellular matrix production of human adult dermal fibroblasts
}

\author{
MONICA BENVENUTO ${ }^{1}$, ROSANNA MATTERA ${ }^{1}$, MARTINO TONY MIELE ${ }^{2}$, \\ MARIA GABRIELLA GIGANTI ${ }^{1}$, ILARIA TRESOLDI ${ }^{1}$, LOREDANA ALBONICI ${ }^{1}$, \\ VITTORIO MANZARI $^{1}$, ANDREA MODESTI $^{1}$, LAURA MASUELLI $^{3 *}$ and ROBERTO BEI ${ }^{1 *}$
}

\begin{abstract}
Departments of ${ }^{1}$ Clinical Sciences and Translational Medicine and ${ }^{2}$ Experimental Medicine, University of Rome 'Tor Vergata', I-00133 Rome; ${ }^{3}$ Department of Experimental Medicine, University of Rome 'Sapienza', I-00161 Rome, Italy
\end{abstract}

Received January 30, 2019; Accepted July 16, 2019

DOI: $10.3892 /$ etm.2019.7872

\begin{abstract}
The extracellular matrix (ECM) creates a tissue microenvironment able to regulate cellular signaling. The loss of ECM plasticity is associated with several pathologies, especially those involving chronic inflammation, therefore, the ECM represents a potential therapeutic target for certain conditions. The present study investigated the effects of a natural multi-component compound formulation, Galium-Heel ${ }^{\circledR}$, on the growth, morphology and ECM production of human dermal fibroblasts (HDF). The effects of the formulation on HDF growth and morphology were assessed by sulforhodamine B assay, trypan blue exclusion staining, FACS and ultrastructural analyses. The effect of the compound on reactive oxygen species production by HDF was performed by dichlorofluorescin diacetate assay. The expression of ECM components, matrix metalloproteinases (MMPs) and signaling molecules was analyzed by western blot analysis. The present results demonstrated that Galium-Heel ${ }^{\circledR}$ did not significantly affect HDF growth, survival, cell cycle or morphology indicating the biocompatibility of the formulation. The formulation demonstrated antioxidant activity. Galium-Heel ${ }^{\circledR}$ was able to modulate ECM by regulating collagens (type I and III) and MMPs-3 and -7 expression. In addition, the formulation was able to regulate molecules involved in TGF- $\beta$ signalling, including mitogen activated kinase-like protein, GLI family zinc finger 2 and pro-survival proteins such as AKT. The present results demonstrating the effects of a natural multi-component
\end{abstract}

Correspondence to: Professor Roberto Bei, Department of Clinical Sciences and Translational Medicine, University of Rome 'Tor Vergata', Via Montpellier 1, I-00133 Rome, Italy

E-mail: bei@med.uniroma2.it

*Contributed equally

Key words: extracellular matrix, fibroblasts, Galium-Heel ${ }^{\circledR}$, natural compound, collagen compound on ECM composition, highlighted the possibility of pharmacologically modulating ECM molecules. The recovery and the maintenance of ECM homeostasis might be considered as a potential therapeutic goal to ameliorate pathological conditions.

\section{Introduction}

Over the past decades, the connective tissue has been considered not only as a mechanical support structure for a tissue but also as a biologically active component of the tissue itself (1-3). The extracellular matrix (ECM) is a dynamic, living structure, which is continuously remodeled and involved in both physiological and pathological processes (1-3).

Accordingly, the analysis of ECM remodeling represents an attractive topic for investigation. The loss of ECM plasticity (i.e. the dysregulation of ECM turnover and barrier effect) is a key factor for the onset and the progression of a number of neoplastic, degenerative and inflammatory diseases $(4,5)$. In these diseases, the structure and function of the ECM are affected by persistent low-grade chronic systemic inflammation (LGCSI). LGCSI contributes to the development of insulin resistance, dyslipidemia, atherogenesis, type II diabetes and hypertension thus promoting cardiometabolic disease (6). In addition, several cytokines are produced in tissues affected by LGCSI that can affect the homeostasis of ECM (6). These alterations trigger the pathological process and promote both onset and progression of a disease (7). The loss of ECM homeostasis caused by LGCSI initially induces an increase of matrix solubility and then the deposition of disorganized collagens (types I, III and IV). The altered collagen turnover leads to tissue fibrosis (8). Accordingly, the ECM shifts from 'plasticity' to 'rigidity' $(9,10)$. Within collagen types, collagen type III is directly responsible for the elastic properties of the connective tissue and it is involved in numerous fibrotic diseases $(11,12)$. Various studies corroborated the pathophysiological role of the ECM, making it a potential therapeutic target (13-15). The analysis of the effects of some natural substances on ECM remodeling may lead to the development of a pharmacological approach for the modulation of ECM turnover. 
The aim of the current study was to analyze the effect of a natural multi-component compound formulation named Galium-Heel ${ }^{\circledR}$ on the growth, morphology and ECM production of human skin fibroblasts. The present findings may provide basis for the development of a new pharmacological approach to counteract local abnormal ECM remodeling.

\section{Materials and methods}

Materials and reagents. Galium-Heel ${ }^{\circledR}$ is manufactured by Biologische Heilmittel Heel GmbH. Sodium chloride 0.9\% was obtained from Eurospital. Galium-Heel ${ }^{\circledR}$ (from here on termed Galium) contains: Acidum nitricum, Apis mellifica, argentum metallicum, aurum metallicum, Betula pendula, calcium fluoratum, Caltha palustris, Clematis recta, Echinacea, Galium mollugo, Galium aparine, Hedera helix, Juniperus communis, Ononis spinosa, phosphorus, Pyrogenium Nosode, Saponaria officinalis, Sedum acre, Sempervivum tectorum ssp., Thuja occidentalis, Urtica urens (Table I). Components were dissolved in sodium chloride $0.9 \%$.

Sulforhodamine B (SRB), trypan blue and Amicon centricon 100 and 30 micro concentrators were purchased from Sigma-Aldrich (Merck KGaA). SimplyBlue SafeStain was purchased from Invitrogen (Thermo Fisher Scientific, Inc.). Rabbit polyclonal antibody against collagen type I (cat. no. NB600-408; 1:1,000) was obtained from Novus Biologicals, LLC. Rabbit polyclonal antibody against collagen type III (cat. no. AB747; 1:300) was purchased from Chemicon International. Rabbit polyclonal antibodies against matrix metalloproteinase (MMP)-2, -3, -7 (cat. no. SA-384; 1:500) were obtained from Enzo Life Sciences. Rabbit monoclonal antibody against AKT (C67E7; cat. no. 4691; 1:1,000), rabbit monoclonal antibody against phosphorylated (p)-AKT (Ser473; D9E; cat. no. 4060; 1:1,000) were obtained from Cell Signaling Technology. Mouse monoclonal antibody against JNK/mitogen-activated protein kinase 9 (SAPK) 1 (cat. no. BD 610627; 1:250), mouse monoclonal antibody against JNK/SAPK (pT183/pY185; cat. no. BD 612540; 1:250), mouse monoclonal antibody against p38 $\alpha /$ SAPK2a (cat. no. BD $612168 ; 1: 1,000)$ and mouse monoclonal antibody against p38 mitogen activated kinase-like protein (MAPK; pT180/pY182; cat. no. BD 612280; 1:200) were obtained from BD Pharmingen (BD Biosciences). Rabbit polyclonal antibody against extracellular signal-regulated kinase (ERK)1/2 (C-14; cat. no. sc-154; 1:300), mouse monoclonal antibody against p-ERK (E-4; cat. no. sc-7383; 1:300) and rabbit polyclonal antibody against GLI family zinc finger 2 (GLI-2; H-300; cat. no. sc-28674; 1:200) were obtained from Santa Cruz Biotechnology, Inc. Rabbit polyclonal antibody against fibronectin (cat. no. F3648; $1: 1,000)$, rabbit polyclonal antibody against actin (cat. no. A5060; 1:500) and peroxidase-conjugated goat anti-mouse polyclonal (cat. no. A4416; 1:5,000) or anti-rabbit polyclonal (cat. no. A6154; 1:10,000) immunoglobulin (Ig)G were obtained from Sigma-Aldrich (Merck KGaA).

Cell lines and treatments. Human adult fibroblasts (HDF), purchased from Cell Applications, Inc. (cat. no. 106-05a), and previously characterized H-Meso-1 cells (16) were maintained in DMEM high glucose (Aurogene s.r.l.) containing 10\% fetal bovine serum (FBS) (Aurogene s.r.l), $100 \mathrm{U} / \mathrm{ml}$ penicillin and $100 \mu \mathrm{g} / \mathrm{ml}$ streptomycin. Cells were cultured at $37^{\circ} \mathrm{C}$ in a humidified incubator with an atmosphere of $5 \% \mathrm{CO}_{2}$.

For the treatments, cells were incubated for the indicated times in the presence of Galium (dose range: 1:2 to 1:16) or vehicle control (sodium chloride 0.9\%; CTR; $1: 2$ to $1: 16$ ) re-suspended in DMEM containing $0.2 \%$ bovine serum albumin (BSA) (Sigma-Aldrich; Merck KGaA), $100 \mathrm{U} / \mathrm{ml}$ penicillin and $100 \mu \mathrm{g} / \mathrm{ml}$ streptomycin.

$S R B$ assay. Cells were seeded at a density of $5 \times 10^{3} /$ well in 96-well plates and incubated at $37^{\circ} \mathrm{C}$ to allow cell attachment. After $24 \mathrm{~h}$, the medium was changed and the cells were treated with Galium or sodium chloride and incubated for 24,48 or $72 \mathrm{~h}$ at concentrations of $1: 2,1: 4,1: 8$ or $1: 16$ in DMEM $0.2 \%$ BSA. The cells were then fixed with cold trichloroacetic acid (final concentration 10\%; Sigma-Aldrich; Merck KGaA) for $1 \mathrm{~h}$ at $4^{\circ} \mathrm{C}$. After four washes with distilled water, the plates were air-dried and stained for $30 \mathrm{~min}$ at room temperature with $0.4 \%$ (wt/vol) SRB in 1\% acetic acid (Sigma-Aldrich; Merck $\mathrm{KGaA}$ ). After four washes with $1 \%$ acetic acid to remove the unbound dye, the plates were air-dried, and cell-bound SRB was dissolved with $100 \mu \mathrm{l} /$ well of $10 \mathrm{mM}$ unbuffered Tris base solution (Sigma-Aldrich; Merck KGaA). The optical density (O.D.) of the samples was determined at $540 \mathrm{~nm}$ with a spectrophotometric plate reader (Multiskan FC; Thermo Fisher Scientific, Inc.). The percentage survival of the cultures treated with Galium was calculated by normalizing their O.D. values to each control culture treated with sodium chloride at the same dilution (considered as 100\%). The experiments were performed in triplicate and repeated three times. H-Meso-1 cells treated with $100 \mu \mathrm{M}$ apigenin (Sigma-Aldrich; Merck $\mathrm{KGaA}$ ) were used as the positive control for the inhibition of cell growth. The percentage of surviving cells treated with apigenin was calculated by normalizing the O.D. value to that of the control cultures treated with DMSO $(\leq 0.1 \%)$, which is a solvent of apigenin (17).

Trypan blue exclusion test. Cells were seeded at a density of $5 \times 10^{4} /$ well in 24 -well plates and incubated at $37^{\circ} \mathrm{C}$ to allow cell attachment. After 24-h, the medium was changed and the cells were treated with Galium or sodium chloride and incubated for 24,48 or 72 -h at concentrations of 1:2 and 1:4 in DMEM $0.2 \%$ BSA. After 24, 48 and $72 \mathrm{~h}$ of adherence, cells from each well were harvested and stained with trypan blue for $2 \mathrm{~min}$ at room temperature, then counted with an Olympus IX50 inverted light microscope (magnification, x100) (18). Percentage of cell death was determined by dividing dead cells by the total number of cells x100 (19). Experiments were performed in triplicate and repeated three times. H-Meso-1 cells treated with apigenin $(100 \mu \mathrm{M})$ were used as the positive control for the inhibition of cells survival.

Fluorescent measurement of reactive oxygen species (ROS). To detect ROS production in HDF cells, 2',7'-dichlorofluorescin diacetate (DCF-DA; Sigma-Aldrich; Merck KGaA) was used. In brief, $2.5 \times 10^{5}$ cells were seeded into six-well plates and incubated at $37^{\circ} \mathrm{C}$ to allow cell attachment before treatment. After two PBS washes, cells were incubated with $10 \mu \mathrm{M}$ DCF-DA in PBS at $37^{\circ} \mathrm{C}$ and $5 \% \mathrm{CO}_{2}$ in the dark for $30 \mathrm{~min}$ (20). Following 
Table I. Concentration of Galium-Heel ${ }^{\circledR}$ components.

\begin{tabular}{lc}
\hline Component $^{\mathrm{a}}$ & Concentration \\
\hline Acidum nitricum & $0.55 \mathrm{ng}$ \\
Apis mellifica & $0.0055 \mathrm{pg}$ \\
Aurum metallicum & $0.055 \mathrm{pg}$ \\
Caltha palustris & $1.1 \mu \mathrm{g}$ \\
Clematis recta & $0.165 \mu \mathrm{g}$ \\
Echinacea & $0.0165 \mu \mathrm{g}$ \\
Galium aparine & $0.88 \mu \mathrm{g}$ \\
Galium mollugo & $0.88 \mu \mathrm{g}$ \\
Hedera helix & $0.165 \mu \mathrm{g}$ \\
Juniperus communis & $0.165 \mu \mathrm{g}$ \\
Ononis spinosa & $0.165 \mu \mathrm{g}$ \\
Phosphorus & $5.5 \mathrm{pg}$ \\
Pyrogenium Nosode & $5.5 \mathrm{ng}$ \\
Saponaria officinalis & $0.55 \mu \mathrm{g}$ \\
Sedum acre & $1.1 \mu \mathrm{g}$ \\
Sempervivum tectorum ssp. & $0.11 \mu \mathrm{g}$ \\
Thuja occidentalis & $1.65 \mu \mathrm{g}$ \\
Urtica urens & $4.4 \mu \mathrm{g}$ \\
Argentum metallicum & $5.5 \mathrm{pg}$ \\
Calcium fluoratum & $5.5 \mathrm{pg}$ \\
Betula pendula & $0.011 \mathrm{mg}$ \\
\hline
\end{tabular}

${ }^{\mathrm{a} O n e ~ v i a l ~ c o n t a i n s ~} 1.1 \mathrm{ml}(1.1 \mathrm{~g})$

two washes, cells were treated with Galium or sodium chloride at the dilution of 1:2 in DMEM $0.2 \%$ BSA and incubated at $37^{\circ} \mathrm{C}$ and $5 \% \mathrm{CO}_{2}$ in the dark for $30 \mathrm{~min}$. Then, cells were harvested, centrifuged at $300 \mathrm{xg}$ for $10 \mathrm{~min}$ at $4^{\circ} \mathrm{C}$ and seeded in 96-well plates $\left(2.5 \times 10^{4}\right.$ cells in $100 \mu \mathrm{l}$ per well). Fluorescence intensity was measured after $30 \mathrm{~min}$ using a spectrophotometric plate reader at an excitation wavelength of $495 \mathrm{~nm}$ and an emission wavelength of $535 \mathrm{~nm}$ (Wallace 1420 Victor; Perkin Elmer Inc.). Malignant mesothelioma H-Meso-1 cells treated with apigenin $(100 \mu \mathrm{M})$ were used as the positive control for the intracellular ROS production.

Fluorescence-activated cell sorting (FACS) analysis. Log-phase growing HDF cells (60\% confluent; $2.5 \times 10^{5} /$ well in six-well plates) were treated with Galium or sodium chloride at the dilution of 1:2 in DMEM 0.2\% BSA. Following a 48-h incubation, cells were harvested, centrifuged at $300 \mathrm{x} \mathrm{g}$ for $10 \mathrm{~min}$ at $4^{\circ} \mathrm{C}$ and washed twice with cold PBS. The cell pellets were re-suspended in $70 \%$ ethanol and incubated for $1 \mathrm{~h}$ at $-20^{\circ} \mathrm{C}$. The cells were then washed twice with cold PBS, centrifuged at $300 \mathrm{x} \mathrm{g}$ for $10 \mathrm{~min}$ at $4^{\circ} \mathrm{C}$, incubated for $1 \mathrm{~h}$ in the dark with propidium iodide at a final concentration of $25 \mu \mathrm{g} / \mathrm{ml}$ in $0.1 \%$ citrate and $0.1 \%$ Triton X-100 (all Sigma-Aldrich; Merck $\mathrm{KGaA}$ ). Samples were then analyzed by flow cytometry using a FACSCalibur ${ }^{\mathrm{TM}}$ cytometer with CellQuest Pro 5.2 software (both BD Biosciences) (21).

Preparation of cell lysates and western blotting. Cells were seeded at a density of $1 \times 10^{6}$ cells in $100-\mathrm{mm}$ tissue culture dishes
$24 \mathrm{~h}$ prior to the addition of Galium or sodium chloride at the dilution of 1:2 in DMEM 0.2\% BSA. Following $48 \mathrm{~h}$ of incubation, the conditioned media was collected and then centrifuged at $600 \mathrm{x} \mathrm{g}$ for $15 \mathrm{~min}$ at $4^{\circ} \mathrm{C}$ in $100 \mathrm{kDa}$ or $30 \mathrm{kDa}$ molecular weight cut-off Centricon tubes. Cells were harvested, washed twice with cold PBS and lysed in RIPA lysis buffer (Triton X-100 $1 \%$, SDS 0.1\%, NaCl 200 mM, Tris $\mathrm{HCl} 50 \mathrm{mM}$ pH 7.5, PMSF $1 \mathrm{mM}$, and $\mathrm{Na}_{3} \mathrm{VO}_{4} 1 \mathrm{mM}$ ). After $30 \mathrm{~min}$ at $4^{\circ} \mathrm{C}$, the mixtures were centrifuged at $12,000 \mathrm{x}$ g for $15 \mathrm{~min}$ at $4^{\circ} \mathrm{C}$, the protein concentration of the lysates were quantified with Bradford assay and then analyzed by western blotting. Handcast gels were prepared from acrylamide and bisacrylamide monomer solutions (cat. no. A3574; Sigma-Aldrich; Merck KGaA). SDS-PAGE and western blot analysis were performed using Mini-PROTEAN Tetra Cell apparatus (Bio-Rad Laboratories, Inc.) according to the manufacturer's instructions. Electrophoresis (cat. no. 161-0732) and blot transfer (cat. no. 161-0734) buffers were purchased from Bio-Rad Laboratories, Inc. Hyper PAGE prestained markers (cat. no. BIO-33066; Bioline; Meridian Bioscience) were used. For western blot analysis, $50 \mu \mathrm{g}$ of cell lysates per lane and $20 \mu \mathrm{l}$ of conditioned media per lane were resolved in $8-12 \%$ gels by SDS-PAGE (150 V for $1 \mathrm{~h})$ and then transferred to nitrocellulose membranes ( $30 \mathrm{~V}$ for $90 \mathrm{~min}$; GE Healthcare). After blocking with 5\% skimmed dry milk in PBS overnight at $4^{\circ} \mathrm{C}$, the membranes were incubated overnight at $4^{\circ} \mathrm{C}$ with the specific primary antibodies at the dilution suggested by the manufacturers (Materials and reagents section). Following washes, the membranes were incubated with peroxidase-conjugated goat anti-mouse or anti-rabbit $\mathrm{IgG}$ antibodies for $1 \mathrm{~h}$ at room temperature. Protein bands were visualized by enhanced chemiluminescence (LiteABlot Plus; Euroclone S.p.A.) (22). Equal loading of conditioned media on the gel was confirmed by Coomassie blue staining. Briefly, after SDS-PAGE the gel was rinsed 3 times for 5 min with deionized water, stained with SimplyBlue SafeStain for $1 \mathrm{~h}$ at room temperature, and then washed 2 times for $1 \mathrm{~h}$ with water. Densitometry was performed using Image J 1.42q software (National Institutes of Health) after blot scanning (HP Scanjet 4890 Photo Scanner; Hewlett-Packard).

Ultrastructural analysis. Ultrastructural analysis was performed on HDF cells $24 \mathrm{~h}$ following treatment with Galium or sodium chloride at the dilution of 1:2 in DMEM 0.2\% BSA. Cells were fixed with $2.5 \%$ glutaraldehyde in PBS at $4{ }^{\circ} \mathrm{C}$ for 48-h, and processed for transmission electron microscopy (TEM), following routine procedures $(23,24)$. Briefly, cells were post-fixed with $1.33 \%$ osmium tetroxide at $4^{\circ} \mathrm{C}$ for $1 \mathrm{~h}$, dehydrated in graded alcohols $\left(30 \%-50 \%-70 \%-95 \%-100 \%\right.$ at $\left.4{ }^{\circ} \mathrm{C}\right)$, and then embedded in Epon 812 resin (Fisher Chemical Co.). The resin was allowed to polymerize in a dry oven at $60^{\circ} \mathrm{C}$ overnight. Thin $(1 \mu \mathrm{M})$ and ultrathin $(900 \AA)$ sections were cut on a Reichert ultra-microtome, stained with uranyl acetate and lead citrate (3 min each at room temperature), and observed under a Philips Morgagni 268D transmission electron microscope at magnifications between $\times 7,000$ and x28,000.

Statistical analysis. Statistical analyses were performed with GraphPad Prism 5.0 software (GraphPad Software, Inc.). Data were presented as the mean \pm SD. Data distribution of cell survival and trypan blue exclusion test were 

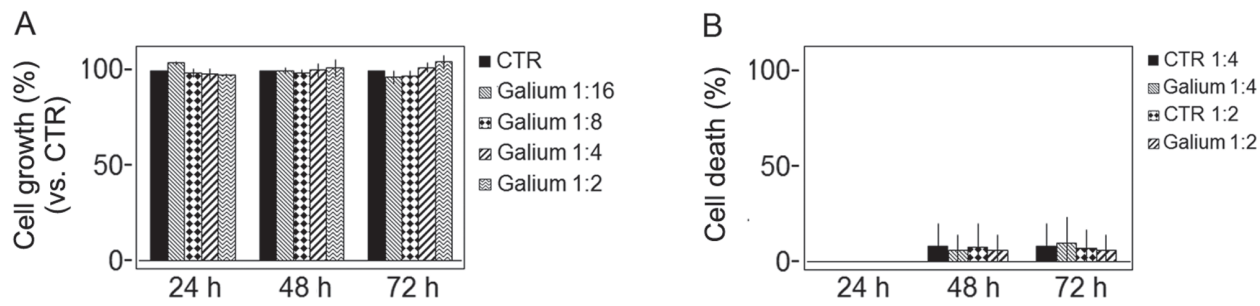

Figure 1. Effects of Galium on HDF cell survival and death. (A) Survival and viability of HDF were assessed by the sulforhodamine B and (B) trypan blue exclusion assays 24, 48 and $72 \mathrm{~h}$ post-treatment with CTR or Galium in DMEM 0.2\% BSA. The percentage of surviving cells treated with Galium was calculated by normalizing the optical density value to each control culture treated with sodium chloride at the same dilution (considered $100 \%)$. The percentage of cell death was compared with the total number of cells. Results are expressed as the mean \pm SD of three independent experiments performed in triplicate. Galium, Galium-Heel ${ }^{\circledast}$; HDF, human dermal fibroblasts; CTR, sodium chloride.

preliminarily verified by Kolmogorov-Smirnov test, and data sets were analyzed by one-way analysis of variance followed by Newman-Keuls post-hoc test. Data distribution of ROS production and FACS analysis, and differences in the intensity of immunoreactive bands were analyzed by two-tailed Student's t-test. $\mathrm{P}<0.05$ was considered to indicate statistical significance.

\section{Results}

Galium does not significantly affect HDF cell growth or death. The survival of HDFs was evaluated by SRB assay after treatment with increasing doses of Galium or sodium chloride as control (1:2, 1:4, 1:8 and 1:16) for 24,48 and $72 \mathrm{~h}$. The percentage of cell survival following treatment with Galium was compared with cells treated with sodium chloride. No significant differences between Galium and CTR were observed ( $\mathrm{P}>0.05$; Fig. 1A). In addition, a Trypan blue exclusion test was performed to test cell viability after treatment with increasing doses of Galium or sodium chloride (1:2 and 1:4) for 24, 48 and $72 \mathrm{~h}$. No significant differences between treatments were observed ( $\mathrm{P}>0.05$; Fig. 1B). H-Meso- 1 cells treated with apigenin $(100 \mu \mathrm{M})$ were used as control. Apigenin significantly inhibited H-Meso-1 cell survival (cell growth: $65,37,22 \%$ for apigenin vs. $100 \%$ for control after 24,48 and $72 \mathrm{~h}$, respectively; $\mathrm{P}<0.01$ ) and promoted cell death in a time-dependent manner (cell death: 49, 67, 84\% for apigenin vs. 2, 2, 3\% for control after 24,48 and $72 \mathrm{~h}$, respectively; $\mathrm{P}<0.01$; data not shown).

Galium significantly decreases intracellular ROS production in HDF cells. A DCF-DA assay was performed to determine the effect of Galium on the intracellular ROS production in HDF. Galium induced a significant decrease of intracellular ROS production when compared with the control $(\mathrm{P}<0.01$; Table II). H-Meso-1 cells treated with apigenin $(100 \mu \mathrm{M})$ were used as a positive control for monitoring the intracellular ROS production. Apigenin significantly increased the production of ROS in H-Meso-1 cells $(3,353,636 \pm 272,041$ for apigenin vs. $184,118 \pm 3,530$ for control; $\mathrm{P}<0.001$; data not shown).

Galium does not significantly affect cell cycle distribution. In order to evaluate the effect of Galium on cell cycle distribution, FACS analysis of DNA content was performed on HDF cells treated with Galium or sodium chloride at the dilution of 1:2. No significant changes were observed in any of the different phases of the cell cycle following Galium treatment compared with control cells treated with sodium chloride ( $\mathrm{P}>0.05$; Table III).

Effect of Galium on the expression of extracellular matrix molecules and MMPs. The effect of Galium on the expression of extracellular matrix molecules (collagen type I and III, fibronectin) and metalloproteinases (MMP-2, -3, -7) in HDF was evaluated by western blot analysis $48 \mathrm{~h}$ following Galium or sodium chloride treatments. The analysis was performed both in HDF lysates (Fig. 2A and C) and in the conditioned medium (Fig. 2B and D). Galium treatment significantly decreased the expression of collagen type III both in the cell lysate $(\mathrm{P}<0.05)$ and in the conditioned medium $(\mathrm{P}<0.01)$. Conversely, collagen type I was increased following Galium treatment both at the intracellular level $(\mathrm{P}<0.01)$ and in the extracellular space $(\mathrm{P}<0.001)$. Collagen type III/I ratio was 0.81 for CTR vs. 0.43 for Galium in the cell lysate and 1.0 for CTR vs. 0.59 for Galium in the extracellular space. The expression of fibronectin was not affected by Galium treatment. MMP-3 $(\mathrm{P}<0.01)$ and MMP-7 $(\mathrm{P}<0.01)$ significantly decreased in the cell lysates following Galium treatment. Conversely, MMP-3 $(\mathrm{P}<0.05)$ increased in the extracellular space compared with CTR (Fig. 2). Galium treatment did not affect the expression of MMP-2 (Fig. 2).

Galium upregulated expression and activation of pro-survival signaling pathway molecules. To evaluate whether Galium affected the expression and phosphorylation of MAPKs, western blot analysis was performed after treating HDF with Galium or sodium chloride for $48 \mathrm{~h}$.

The levels of p-ERK1, p-ERK2, p-p38-MAPK $\alpha$, p-JNK p46 and p-JNK p54 proteins were compared with their respective total proteins. Results demonstrated that Galium treatment significantly decreased the levels of phosphorylation of ERK1/2 (p-ERK1, P<0.05; p-ERK2, P<0.01) compared with CTR (Fig. 3). In addition, Galium-treated cells demonstrated significantly reduced phosphorylation of JNK p54 $(\mathrm{P}<0.01)$ and JNK p46 $(\mathrm{P}<0.05)$ compared with the CTR-treated cells (Fig. 3). Conversely, p38-MAPK $\alpha$ phosphorylation was increased following Galium treatment $(\mathrm{P}<0.001)$ compared with sodium chloride treatment (Fig. 3). Furthermore, the effect of Galium treatment on the expression of pro-survival kinase AKT was evaluated. Results demonstrated that Galium significantly increased the p-AKT protein levels compared with CTR $(\mathrm{P}<0.05$; Fig. 3). Finally, GLI-2 expression was 
Table II. Effects of Galium on the intracellular ROS production in HDF.

\section{Treatment}

Intracellular ROS production

$\begin{array}{ll}\text { Sodium chloride 1:2 (CTR) } & 320,564 \pm 2,251 \\ \text { Galium } 1: 2 & 283,354 \pm 11,411^{\mathrm{a}}\end{array}$

${ }^{\mathrm{a}} \mathrm{P}<0.01$ vs. control. The results are reported as the mean of the fluorescence intensity $\pm \mathrm{SD}$ values from three experiments performed in triplicate. Galium, Galium-Heel ${ }^{\circledR}$; HDF, human dermal fibroblasts; ROS, reactive oxygen species.

significantly decreased after Galium treatment $(\mathrm{P}<0.001)$ when compared with CTR treatment (Fig. 3).

Ultrastructural analysis of HDF cells treated with Galium. Ultrastructural analysis was performed on HDF cells 24-h following treatment with Galium or sodium chloride at the dilution of 1:2 in DMEM 0.2\% BSA. Sodium chloride-treated HDF cells displayed an elongated morphology with elongated centrally located nuclei, essentially formed by euchromatin with poor heterochromatin and well organized nucleoli (Fig. 4A). Condensed mitochondria, dilated rough endoplasmic reticulum, and primary and secondary lysosomes were also observed (Fig. 4A). Intermediate filaments were visible in the cytoplasm (Fig. 4C). Galium-treated cells had similar appearance to CTR-treated cells (Fig. 4B). However, an increase in the polymerization of intermediate filaments was observed in Galium-treated cells (Fig. 4D).

\section{Discussion}

The ECM produces a tissue microenvironment able to affect and regulate cellular signalling (1-3). It is fundamental for optimal cell crosstalk to maintain ECM homeostasis (1-3). The loss of ECM plasticity, which is dependent on the anabolic and catabolic phases, is associated with the onset of several pathologies, especially those involving chronic inflammation. Persistent LGCSI causes the ECM to lose its plasticity, making it become rigid with consequent fibrotic degeneration (4-6). Accordingly, it is important to counteract the vicious cycle of inflammation and ECM turnover alterations by primary therapeutic intervention. However, the therapy needs to affect several different aspects involving both the inflammatory processes leading to reactive oxygen species production and ECM turnover mechanisms.

The present study aimed to investigate the activity of a natural multi-component compound formulation named Galium-Heel ${ }^{\circledR}$ on HDF growth, morphology and ECM production. The results demonstrated that Galium-Heel ${ }^{\circledR}$ had no significant effect on the cell cycle, cell growth, cell survival and cell morphology, which highlighted the biocompatibility of Galium-Heel ${ }^{\circledR}$. The observed antioxidant activity of Galium-Heel ${ }^{\circledR}$ on HDF might be due to its components Galium aparine, Sedum acre, Sempervivum tectorum or Urtica urens, which are able to regulate redox processes (25-27). The modifications of collagen type I and type III and MMP-3, observed after the treatment of
HDF with Galium-Heel ${ }^{\circledR}$ suggested that the multi-component compound formulation had a role in the modulation of ECM anabolic and catabolic phases. Galium-Heel ${ }^{\circledR}$ treatment significantly decreased the expression of collagen type III and MMP-3, whilst collagen type I expression increased at the intracellular level. In addition, Galium-Heel ${ }^{\circledR}$ significantly decreased the expression of collagen type III and increased collagen I and MMP-3 expression in the extracellular space. Increased MMP-3 expression might support subsequent ECM remodelling (28). Tumour necrosis factor- $\alpha$ (TNF- $\alpha$ ) is able to increase the expression of MMP-3 and subsequent ECM remodelling with the process dependent on $\mathrm{p} 38$ phosphorylation (29). This effect can be reversed by TGF- $\beta$ via activation of MAPKs namely ERK1/2 (30). The present results demonstrated that Galium-Heel ${ }^{\circledR}$ may have a similar effect to TNF- $\alpha$ acting as a TGF- $\beta$ inhibitor, inducing activation of $\mathrm{p} 38$ and increasing the expression of MMP-3 whilst inhibiting ERK1/2 activity. Increased expression of MMP-3 could be responsible for the decrease in collagen type III/I ratio observed in the cell lysate and extracellular space following Galium-Heel ${ }^{\circledR}$ treatment. TGF- $\beta$ is able to induce fibrosis by upregulating the expression of collagen type III and increasing the collagen type III/I ratio (31). Collagen type III is considered a marker of lung fibrosis (32). In addition, it has been demonstrated that collagen type III expression is increased in liver cirrhosis and this increased expression is related to the development of portal hypertension (33).

GLI proteins are the effectors of the Hedgehog signalling pathway (34). GLI-2 is an early gene target of the TGF- $\beta /$ SMAD cascade independent of Hedgehog signalling (34). Hedgehog and TGF- $\beta$ signalling pathways overlap in GLI-2, which integrates those signals to promote tissue fibrosis (35). The present study observed that Galium-Heel ${ }^{\circledR}$ decreased the expression of GLI-2 therefore, it could potentially prevent the early stages of fibrosis by maintaining homeostasis of the ECM. The effects of Galium-Heel ${ }^{\circledR}$ on ECM modulation might be due to certain components contained in the formulation including: i) Acidum nitricum, which participates as a nitric oxide (NO) donor through the nitrate/nitrite/NO pathway, and is involved in the collagen synthesis mechanism (36-39); ii) argentum metallicum and aurum metallicum are donors of the trace elements silver and gold respectively, and exert an antioxidant effect (40); iii) aurum metallicum regulates MMP expression (41); iv) phosphorus contributes to the tissue inhibitor of metalloproteinases synthetic pathways (42); v) calcium fluoratum is involved in the synthesis of MMP-2 and -9 (43); vi) Caltha palustris promotes collagen synthesis (44); vii) Juniperus communis controls the synthesis of collagen type I and III (45); viii) Betula pendula reduces the expression of MMP-3 (46,47); and ix) Pyrogenium and Thuja occidentalis exert an immunomodulating effect through stimulation of $\mathrm{T}$ helper type I immune response and the synthesis of MMPs (48-50). In addition, it should be considered that the various components contained in the formulation could have an additive or a synergistic effect. Previous studies by our group demonstrated that the simultaneous administration of polyphenols exerts additive or synergistic antitumoral effects (51-53). Finally, an increase in the polymerization of intermediate filaments was observed in Galium-treated cells by ultrastructural analysis. 
Table III. Effect of Galium on cell cycle distribution.

\begin{tabular}{lcccccccc}
\hline Treatment & Sub-G1 & P-value & G0/G1 & P-value & S & P-value & G2/M & P-value \\
\hline Sodium chloride 1:2 (CTR) & $1.70 \pm 0.71$ & & $89.70 \pm 1.44$ & & $3.05 \pm 0.11$ & & $5.65 \pm 0.86$ & \\
Galium 1:2 & $1.90 \pm 1.05$ & $>0.05$ & $90.89 \pm 1.93$ & $>0.05$ & $2.67 \pm 0.03$ & $>0.05$ & $4.66 \pm 0.92$ & $>0.05$ \\
\hline
\end{tabular}

Results are expressed as the mean \pm SD of two independent experiments performed in duplicate. Galium, Galium-Heel ${ }^{\circledR}$.

A

C
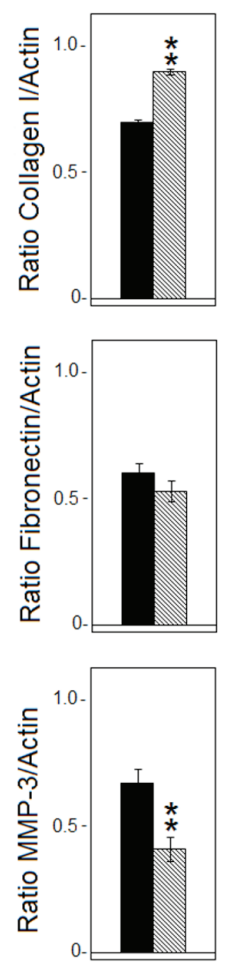

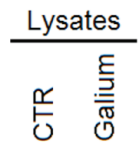

Collagen I

Collagen III

Fibronectin

MMP-2

MMP-3

MMP-7

Actin
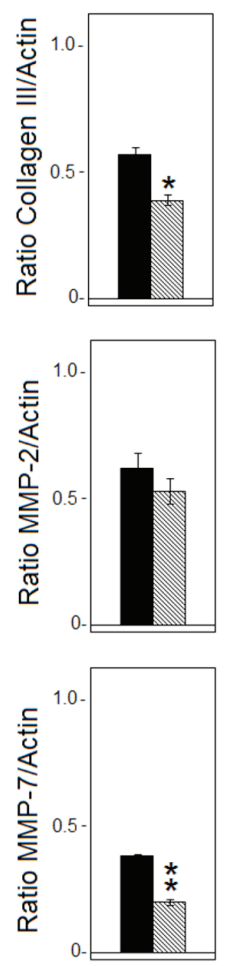

- CTR

$\mathbb{Q}$ Galium
B

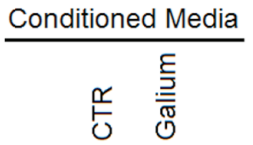

Collagen I

Collagen III

Fibronectin

MMP-2

MMP-3

MMP-7

Coomassie

D
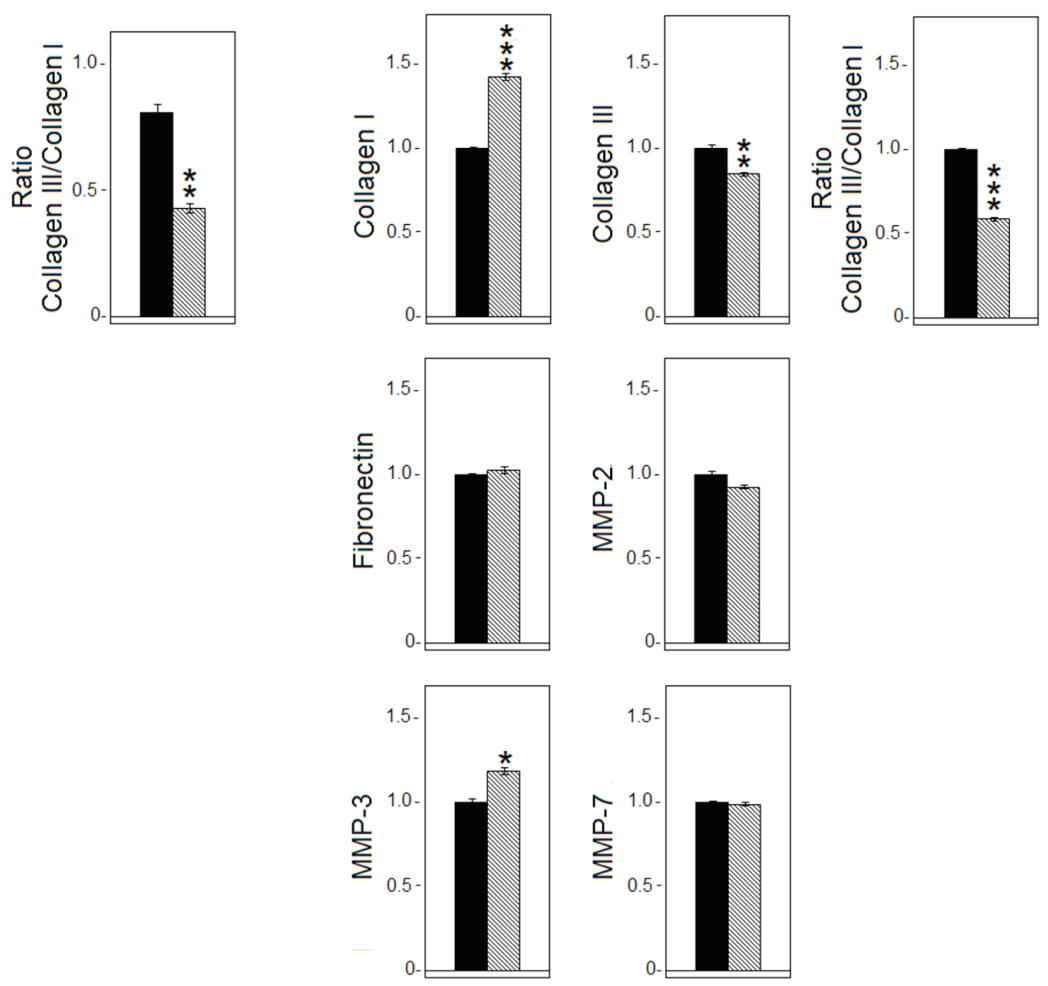

- CTR

$\mathbb{Q}$ Galium

Figure 2. Effects of Galium on the expression of extracellular matrix molecules and MMPs. (A) Expression of collagen type I and type III, fibronectin, MMP-2, MMP-3 and MMP-7 in cell lysates derived from HDF cells treated for $48 \mathrm{~h}$ with CTR or Galium at the dilution of 1:2 in DMEM 0.2\% BSA was assessed by western blot analysis. (B) Expression of collagen type I and III, fibronectin, MMP-2, MMP-3 and MMP-7 in the conditioned media derived from HDF-treated cells was assessed by western blot analysis. Equal loading of protein on the gel was confirmed by Coomassie blue staining of the gel. Each protein was normalized to total protein loading assessed by Coomassie blue staining. (C and D) Densitometric ratios and statistical analysis of the respective blots for sodium chloride- and Galium-treated cells. Data are expressed as the mean \pm SD of two experiments. ${ }^{*} \mathrm{P}<0.05$, ${ }^{* *} \mathrm{P}<0.01$ and ${ }^{* * *} \mathrm{P}<0.001$ vs. CTR. Galium, Galium-Heel ${ }^{\circledR}$; MMP, matrix metalloproteinase; HDF, human dermal fibroblasts; CTR, sodium chloride. 
A

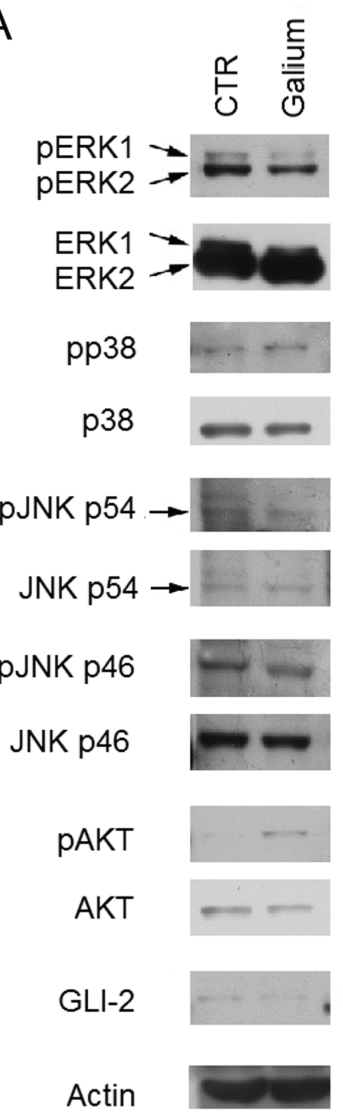

B
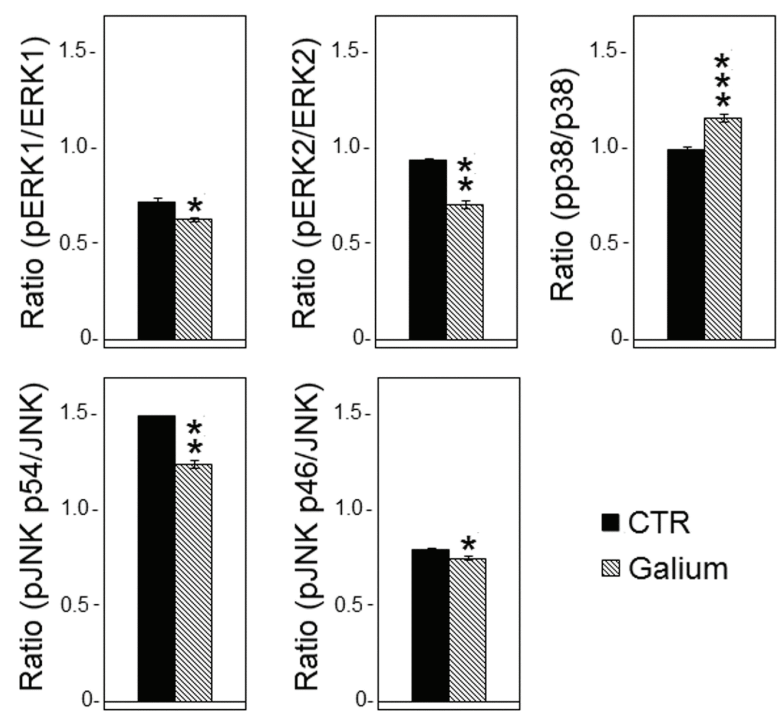

- CTR

$\mathbb{Q}$ Galium
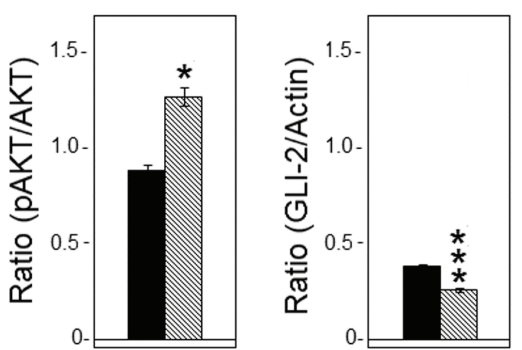

Figure 3. Effects of Galium on the expression and activation of pro-survival signaling pathway molecules. (A) Expression of MAPKs, AKT, GLI-2 was assessed by western blot analysis in cell lysates derived from HDF cells treated for $48 \mathrm{~h}$ with CTR or Galium at the dilution of 1:2 in DMEM $0.2 \%$ BSA (B) Densitometric ratios and statistical analysis of the respective blots for CTR- and Galium-treated cells with phosphorylated data presented as a ratio to the total protein. Data are expressed as the mean \pm SD of two experiments. ${ }^{*} \mathrm{P}<0.05,{ }^{* *} \mathrm{P}<0.01$ and ${ }^{* * * *} \mathrm{P}<0.001$ vs. CTR. Galium, Galium-Heel ${ }^{\circledR} ;$ HDF, human dermal fibroblasts; p, phosphorylated; MAPK, mitogen-activated protein kinase; GLI-2, GLI family zinc finger 2; CTR, sodium chloride.
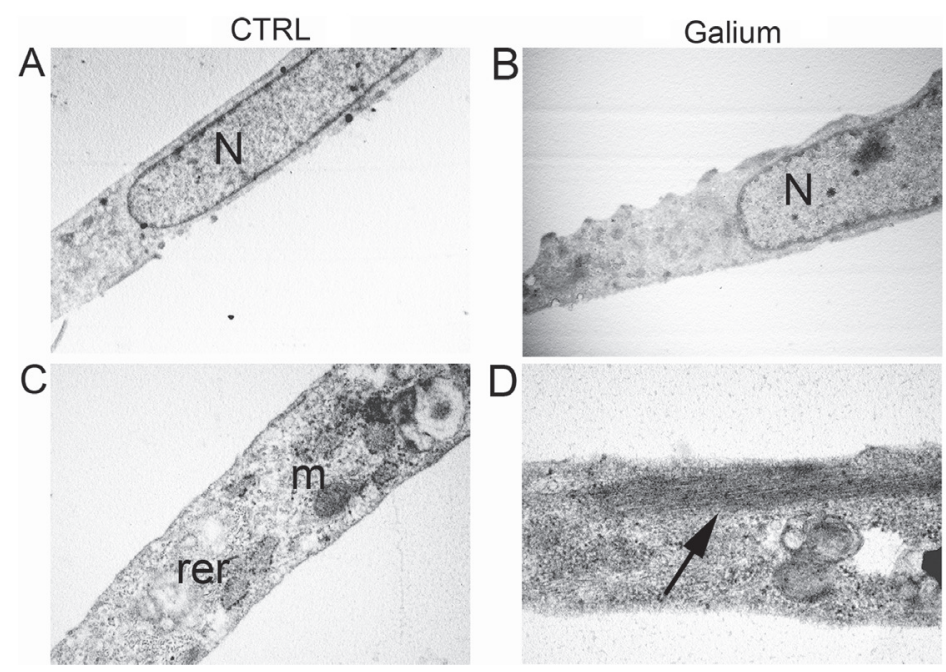

Figure 4. Ultrastructural analysis of HDF cells treated with Galium or sodium chloride (CTRL). (A) Ultrastructural analysis of sodium chloride- and (B) Galium-treated HDF cells at x7,000 magnification. (C) Ultrastructural analysis of sodium chloride- and (D) Galium-treated HDF cells at x28,000 magnification. The arrow indicates an increase in the polymerization of intermediate filaments in Galium-treated cells. Galium, Galium-Heel ${ }^{\circledR}$; HDF, human dermal fibroblasts; $\mathrm{N}$, nucleus; $\mathrm{m}$, mitochondria; rer, rough endoplasmic reticulum.

It has been established that fibroblasts within the connective tissue are able to remodel the ECM (54). Upon ECM remodelling, fibroblasts adapt their cytoskeleton to a different extracellular microenvironment (54), which can affect the viscoelastic and stretching properties of the connective tissue (55). Therefore, the present results suggested that polymerization of the cytoskeleton in Galium-treated HDF might be a consequence of ECM remodelling or that 
ECM remodelling might be a consequence of the fibroblast cytoskeleton polymerization.

Based on the fundamental role of the tissue microenvironment in the onset and maintenance of many pathological conditions, the importance of ECM turnover is crucial, and the recovery of ECM homeostasis can be considered as a potential therapeutic goal. The present results demonstrating the beneficial effects of Galium-Heel ${ }^{\circledR}$ on ECM plasticity highlight that it may be possible to pharmacologically control some mechanisms of ECM metabolism. The present findings may provide basis for the development of novel pharmacological approaches to counteract local abnormal ECM remodeling.

\section{Acknowledgements}

The authors would like to thank Mrs. Barbara Bulgarini (Department of Clinical Sciences and Translational Medicine, University of Rome 'Tor Vergata') for editorial assistance in the preparation of the manuscript.

\section{Funding}

This study was supported by a grant from GUNA S.p.a, (UPB: BeiRCtGUNA) which provided the Galium-Heel ${ }^{\circledR}$. However, this did not influence the authors' scientific neutrality.

\section{Availability of data and materials}

The datasets used and/or analyzed during the current study are available from the corresponding author on reasonable request.

\section{Authors' contributions}

MB performed cell proliferation, western blot analysis, FACS, statistical analysis and analyzed the results. RM performed cell death experiments, reaction oxygen species production, western blot analysis and analyzed the results. MTM performed statistical analysis and analyzed the results. MGG, IT, LA, VM and AM analyzed the results and critically revised the manuscript. LM performed ultrastructural analysis and analyzed the results. RB supervised the project, analyzed the results and wrote the manuscript. All the authors have critically revised the manuscript and gave the final approval of the version to be published.

\section{Ethics approval and consent to participate}

Not applicable.

\section{Patient consent for publication}

Not applicable.

\section{Competing interests}

The present study was partially funded by GUNA S.p.a which provided Galium-Heel ${ }^{\circledR}$. However, this did not influence the authors' scientific neutrality. No products, patents or other commercial interests relate to this study.

\section{References}

1. Nyström A and Bruckner-Tuderman L: Matrix molecules and skin biology. Semin Cell Dev Biol 89: 136-146, 2019.

2. Bei R, Masuelli L, Palumbo C, Tresoldi I, Scardino A and Modesti A: Long-lasting tissue inflammatory processes trigger autoimmune responses to extracellular matrix molecules. Int Rev Immunol 27: 137-175, 2008.

3. Iozzo RV and Gubbiotti MA: Extracellular matrix: The driving force of mammalian diseases. Matrix Biol 71-72: 1-9, 2018.

4. Walker C, Mojares E and Del Río Hernández A: Role of extracellular matrix in development and cancer progression. Int $\mathrm{J}$ Mol Sci 19: pii: E3028, 2018.

5. Li L, Zhao Q and Kong W: Extracellular matrix remodeling and cardiac fibrosis. Matrix Biol 68-69: 490-506, 2018.

6. Minihane AM, Vinoy S, Russell WR, Baka A, Roche HM, Tuohy KM, Teeling JL, Blaak EE, Fenech M, Vauzour D, et al: Low-grade inflammation, diet composition and health: Current research evidence and its translation. Br J Nutr 114: 999-1012, 2015.

7. Theocharis AD, Skandalis SS, Gialeli C and Karamanos NK: Extracellular matrix structure. Adv Drug Deliv Rev 97: 4-27, 2016.

8. Soylemezoglu O, Wild G, Dalley AJ, MacNeil S, Milford-Ward A, Brown $\mathrm{CB}$ and el Nahas AM: Urinary and serum type III collagen: Markers of renal fibrosis. Nephrol Dial Transplant 12: 1883-1889, 1997.

9. Arpino V, Brock M and Gill SE: The role of TIMPs in regulation of extracellular matrix proteolysis. Matrix Biol 44-46: 247-254, 2015.

10. Randelli F, Menon A, Giai Via A, Mazzoleni MG, Sciancalepore F, Brioschi M and Gagliano N: Effect of a collagen-based compound on morpho-functional properties of cultured human tenocytes. Cells 7: pii: E246, 2018.

11. Karsdal MA, Nielsen MJ, Sand JM, Henriksen K, Genovese F, Bay-Jensen AC, Smith V, Adamkewicz JI, Christiansen C and Leeming DJ: Extracellular matrix remodeling: The common denominator in connective tissue diseases. Possibilities for evaluation and current understanding of the matrix as more than a passive architecture, but a key player in tissue failure. Assay Drug Dev Technol 11: 70-92, 2013.

12. Barascuk N, Vassiliadis E, Larsen L, Wang J, Zheng Q, Xing R, Cao Y, Crespo C, Lapret I, Sabatini M, et al: Development and validation of an enzyme-linked immunosorbent assay for the quantification of a specific MMP-9 mediated degradation fragment of type III collagen-A novel biomarker of atherosclerotic plaque remodeling. Clin Biochem 44: 900-906, 2011.

13. Liang Z, Li T, Jiang S, Xu J, Di W, Yang Z, Hu W and Yang Y: AMPK: A novel target for treating hepatic fibrosis. Oncotarget 8: 62780-62792, 2017.

14. Zhang N, Wei WY, Li LL, Hu C and Tang QZ: Therapeutic potential of polyphenols in cardiac fibrosis. Front Pharmacol 9: 122, 2018.

15. Katoh M: Multi-layered prevention and treatment of chronic inflammation, organ fibrosis and cancer associated with canonical WNT/ $\beta$ catenin signaling activation (Review). Int J Mol Med 42: 713-725, 2018.

16. Reale FR, GriYn TW, Compton JM, Graham S, Townes PL and Bogden A: Characterization of a human malignant mesothelioma cell line (H-MESO-1): A biphasic solid and ascitic tumor model. Cancer Res 47: 3199-3205, 1987.

17. Masuelli L, Benvenuto M, Mattera R, Di Stefano E, Zago E, Taffera G, Tresoldi I, Giganti MG, Frajese GV, Berardi G, et al: In vitro and in vivo anti-tumoral effects of the flavonoid apigenin in malignant mesotelioma. Front Pharmacol 8: 373, 2017.

18. Strober W: Trypan blue exclusion test of cell viability. Curr Protoc Immunol 111: A3.B.1-3, 2015.

19. Benvenuto M, Mattera R, Sticca JI, Rossi P, Cipriani C, Giganti MG, Volpi A, Modesti A, Masuelli L and Bei R: Effect of the BH3 mimetic polyphenol (-)-Gossypol (AT-101) on the in vitro and in vivo growth of malignant mesothelioma. Front Pharmacol 9: 1269, 2018.

20. Masuelli L, Pantanella F, La Regina G, Benvenuto M, Fantini M, Mattera R, Di Stefano E, Mattei M, Silvestri R, Schippa S, et al: Violacein, an indole-derived purple-colored natural pigment produced by Janthinobacterium lividum, inhibits the growth of head and neck carcinoma cell lines both in vitro and in vivo. Tumour Biol 37: 3705-3717, 2016. 
21. Benvenuto M, Mattera R, Masuelli L, Taffera G, Andracchio O, Tresoldi I, Lido P, Giganti MG, Godos J, Modesti A and Bei R: $( \pm)$-Gossypol induces apoptosis and autophagy in head and neck carcinoma cell lines and inhibits the growth of transplanted salivary gland cancer cells in BALB/c mice. Int J Food Sci Nutr 68 : 298-312, 2017

22. Masuelli L, Benvenuto M, Di Stefano E, Mattera R, Fantini M, De Feudis G, De Smaele E, Tresoldi I, Giganti MG, Modesti A and Bei R: Curcumin blocks autophagy and activates apoptosis of malignant mesothelioma cell lines and increases the survival of mice intraperitoneally transplanted with a malignant mesothelioma cell line. Oncotarget 8: 34405-34422, 2017.

23. Masuelli L, Granato M, Benvenuto M, Mattera R, Bernardini R, Mattei M, d'Amati G, D'Orazi G, Faggioni A, Bei R and Cirone M: Chloroquine supplementation increases the cytotoxic effect of curcumin against Her2/neu overexpressing breast cancer cells in vitro and in vivo in nude mice while counteracts it in immune competent mice. OncoImmunology 6: e1356151, 2017.

24. Angelucci C, D'Alessio A, Lama G, Binda E, Mangiola A, Vescovi AL, Proietti G, Masuelli L, Bei R, Fazi B, et al: Cancer stem cells from peritumoral tissue of glioblastoma multiforme: The possible missing link between tumor development and progression. Oncotarget 9: 28116-28130, 2018.

25. Stanković M, Radojević I, Ćurčić M, Vasić S, Topuzović M Čomić L and Marković S: Evaluation of biological activities of goldmoss stonecrop (Sedum acre L.). Turk J Biol 36: 580-588, 2012.

26. Sentjurc M, Nemec M, Connor HD and Abram V: Antioxidant activity of Sempervivum tectorum and its components. J Agric Food Chem 51: 2766-2771, 2003.

27. Marrassini C, Acevedo C, Miño J, Ferraro G and Gorzalczany S: Evaluation of antinociceptive, antinflammatory activities and phytochemical analysis of aerial parts of Urtica urens L. Phytother Res 24: 1807-1812, 2010.

28. Lu P, Takai K, Weaver VM and Werb Z: Extracellular matrix degradation and remodeling in development and disease. Cold Spring Harb Perspect Biol 3: pii: a005058, 2011.

29. Sanchavanakit N, Saengtong W, Manokawinchoke J and Pavasant P: TNF- $\alpha$ stimulates MMP-3 production via PGE2 signalling through the NF-kB and p38 MAPK pathway in a murine cementoblast cell line. Arch Oral Biol 60: 1066-1074, 2015.

30. Yang H, Gao F, Li X, Wang J, Liu H and Zheng Z: TGF- $\beta 1$ antagonizes TNF- $\alpha$ induced up-regulation of matrix metalloproteinase 3 in nucleus pulposus cells: Role of the ERK1/2 pathway. Connect Tissue Res 56: 461-468, 2015.

31. Saed GM, Zhang W, Chegini N, Holmdahl L and Diamond MP Alteration of type I and III collagen expression in human peritoneal mesothelial cells in response to hypoxia and transforming growth factor-beta1. Wound Repair Regen 7: 504-510, 1999.

32. Forel JM, Guervilly C, Farnarier C, Donati SY, Hraiech S, Persico N, Allardet-Servent J, Coiffard B, Gainnier M, Loundou A, et al: Transforming growth factor- $\beta 1$ in predicting early lung fibroproliferation in patients with acute respiratory distress syndrome. PLoS One 13: e0206105, 2018.

33. Rojkind M, Giambrone MA and Biempica L: Collagen types in normal and cirrhotic liver. Gastroenterology 76: 710-719, 1979.

34. Javelaud D, Pierrat MJ and Mauviel A: Crosstalk between TGF- $\beta$ and hedgehog signaling in cancer. FEBS Lett 586: 2016-2025, 2012.

35. Liang R, Šumová B, Cordazzo C,Mallano T,Zhang Y,Wohlfahrt T, Dees C, Ramming A, Krasowska D, Michalska-Jakubus M, et al: The transcription factor GLI2 as a downstream mediator of transforming growth factor- $\beta$-induced fibroblast activation in SSc. Ann Rheum Dis 76: 756-764, 2017.

36. Moncada $\mathrm{S}$ and Higgs A: The L-arginine-nitric oxide pathway. N Engl J Med 329: 2002-2012, 1993.

37. Xia W, Szomor Z, Wang Y and Murrell GA: Nitric oxide enhances collagen synthesis in cultured human tendon cells. J Orthop Res 24: 159-172, 2006

38. Lundberg JO, Weitzberg E and Gladwin MT: The nitrate-nitrite-nitric oxide pathway in physiology and therapeutics. Nat Rev Drug Discov 7: 156-167, 2008.

39. Gilkes DM, Semenza GL and Wirtz D: Hypoxia and the extracellular matrix: Drivers of tumour metastasis. Nat Rev Cancer 14: 430-439, 2014
40. Negahdary M, Chelongar R, Zadeh SK and Ajdary M: The antioxidant effects of silver, gold, and zinc oxide nanoparticles on male mice in in vivo condition. Adv Biomed Res 4: 69, 2015.

41. Hashimoto M, Sasaki JI, Yamaguchi S, Kawai K, Kawakami H, Iwasaki Y and Imazato S: Gold nanoparticles inhibit matrix metalloproteases without cytotoxicity. J Dent Res 94: 1085-1091, 2015.

42. Veerendhar A, Reich R and Breuer E: Phosphorus based inhibitors of matrix metalloproteinases. C R Chim 13: 1191-1202, 2010.

43. Slompo C, Buzalaf CP, Damante CA, Martins GM, Hannas AR, Buzalaf MA and Oliveira RC: Fluoride modulates preosteoblasts viability and matrix metalloproteinases-2 and -9 activities. Braz Dent J 23: 629-634, 2012

44. Suszko A and Obmińska-Mrukowicz B: Effects of polysaccharide fractions isolated from Caltha palustris $\mathrm{L}$. on the activity of phagocytic cells \& humoral immune response in mice with collagen-induced arthritis: A comparison with methotrexate. Indian J Med Res 145: 229-236, 2017.

45. Han X and Parker TL: Anti-inflammatory activity of Juniper (Juniperus communis) berry essential oil in human dermal fibroblasts. Cogent Med 4: 1306200, 2017.

46. Rastogi S, Pandey MM and Kumar Singh Rawat A: Medicinal plants of the genus Betula-traditional uses and a phytochemical-pharmacological review. J Ethnopharmacol 159: 62-83, 2015.

47. Ra HJ, Lee HJ, Jo HS, Nam DC, Lee YB, Kang BH, Moon DK, Kim DH, Lee CJ and Hwang SC: Betulin suppressed interleukin-1 $\beta$-induced gene expression, secretion and proteolytic activity of matrix metalloproteinase in cultured articular chondrocytes and production of matrix metalloproteinase in the knee joint of rat. Korean J Physiol Pharmacol 21: 19-26, 2017.

48. Silacci P, Dayer JM, Desgeorges A, Peter R, Manueddu C and Guerne PA: Interleukin (IL)-6 and its soluble receptor induce TIMP-1 expression in synoviocytes and chondrocytes, and block IL-1-induced collagenolytic activity. J Biol Chem 273: 13625-13629, 1998.

49. Offergeld R, Reinecker C, Gumz E, Schrum S, Treiber R, Neth RD and Gohla SH: Mitogenic activity of high molecular polysaccharide fractions isolated from the cuppressaceae Thuja occidentalis L. enhanced cytokine-production by thyapolysaccharide, g-fraction (TPSg). Leukemia 6 (Suppl 3): 189S-191S, 1992.

50. Sunila ES, Hamsa TP and Kuttan G: Effect of Thuja occidentalis and its polysaccharide on cell-mediated immune responses and cytokine levels of metastatic tumor-bearing animals. Pharm Biol 49: 1065-1073, 2011

51. Masuelli L, Marzocchella L, Focaccetti C, Tresoldi I, Palumbo C, Izzi V, Benvenuto M, Fantini M, Lista F, Tarantino U, et al: Resveratrol and diallyl disulfide enhance curcumin-induced sarcoma cell apoptosis. Front Biosci (Landmark Ed) 17: 498-508, 2012.

52. Masuelli L, Di Stefano E, Fantini M, Mattera R, Benvenuto M, Marzocchella L, Sacchetti P, Focaccetti C, Bernardini R, Tresoldi I, et al: Resveratrol potentiates the in vitro and in vivo anti-tumoral effects of curcumin in head and neck carcinomas. Oncotarget 5: 10745-10762, 2014.

53. Fantini M, Benvenuto M, Masuelli L, Frajese GV, Tresoldi I, Modesti A and Bei R: In vitro and in vivo antitumoral effects of combinations of polyphenols, or polyphenols and anticancer drugs: Perspectives on cancer treatment. Int J Mol Sci 16: 9236-9282, 2015 .

54. Rhee S: Fibroblasts in three dimensional matrices: Cell migration and matrix remodelling. Exp Mol Med 41: 858-865, 2009.

55. Langevin HM, Bouffard NA, Fox JR, Palmer BM, Wu J, Iatridis JC, Barnes WD, Badger GJ and Howe AK: Fibroblast cytoskeletal remodeling contributes to connective tissue tension. J Cell Physiol 226: 1166-1175, 2011.

This work is licensed under a Creative Commons Attribution-NonCommercial-NoDerivatives 4.0 International (CC BY-NC-ND 4.0) License. 